\begin{tabular}{|l|l|}
\hline APR 161997,20$)$ engineering data transmittal & Page 1 of $\frac{1}{1}$ \\
Sta, 37 & 1. edt No 614847 \\
\hline
\end{tabular}

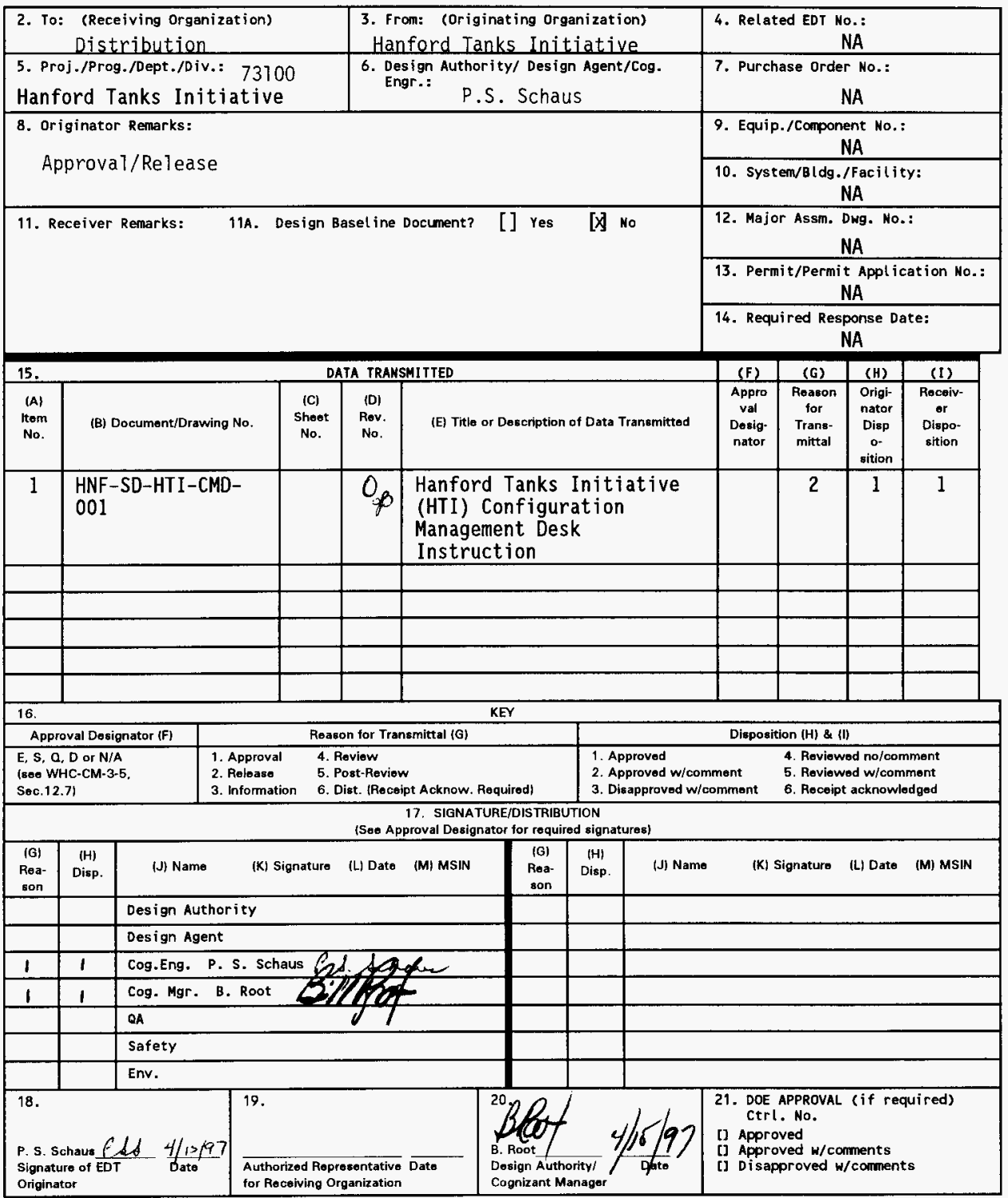




\title{
Hanford Tanks Initiative (HTI) Configuration Management Desk Instruction
}

\author{
K. E. Mckinney \\ Lockheed Mart in Hanford Corporation, Richland, WA 99352 \\ U.S. Department of Energy Contract DE-AC06-96RL13200
}

$\begin{array}{lll}\text { EDT/ECN: } & 614847 & \text { UC: } 2000 \\ \text { Org Code: } 73100 & \text { Charge Code: D26A1 } \\ \text { B\&R Code: } & \text { EW3130010 } & \text { Total Pages: } \text { pt7 } 30^{27}\end{array}$

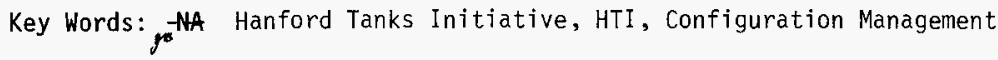

Abstract: The purpose of the document is to provide working level directions for submitting requirements, making changes to the requirements database, and entering Project documentation into the HTI Project information and document management system.

IRADEMARK DISCLAIMER. Reference herein to any specific comercial product, process, or service by trade name, trademark, manufacturer, or otherwise, does not necessarily constitute or imply its endorsement, recommendation, or favoring by the United States Government or any agency thereof or its contractors or subcontractors.

Printed in the United States of America. Io obtain copies of this document, contact: Document Control Services, P.O. Box 950, Mailstop H6-08, Richland WA 99352, Phone (509) 372-2420; Fax (509) 376-4989.
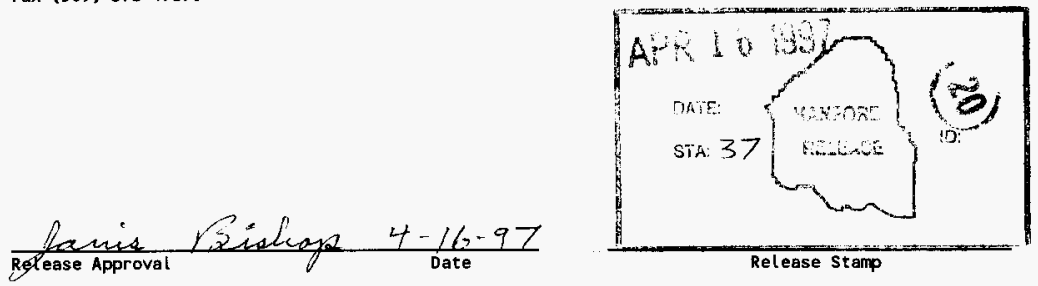

\section{Approved for Public Release}


HNF-SD-HTI-CMD-001, Rev. 0

HANFORD TANK INITIATIVE (HTI) CONFIGURATION MANAGEMENT DESK INSTRUCTION

\author{
Prepared for \\ Lockheed Martin Hanford Corporation
}

February 1997 


\section{HNF-SD-HTI-CMD-001, Rev. 0}

\section{CONTENTS}

1.0 Desk Instruction Purpose 1

2.0 Program Management Element 2

3.0 HTI Requirements Database Change and Document Control Systems Descriptions

3.1 Requirements Database System

3.2 Document Control System (DCS)

3.3 Review \& Sign-off Authority (R/SA) 6

4.0 CM Assessments

5.0 Roles \& Responsibilities

5.1 Document \& Change Originators

5.2 Gatekeepers (GK)

5.3 Requirements Database Administrator (RDA) 8

5.4 DCS Service Centers (DCSC) 8

5.5 HTI Project File Custodian (PFC) 9

5.6 HTI Working File Custodian (WFC) 9

6.0 Processes 10

6.1 Submitting Documents Received from Outside HTI 11

6.2 Submitting Requirements Changes 11

6.3 Changing or Submitting Documents Generated by HTI 12

6.4 Retrieval of Documents \& Review of Unpublished Changes

7.0 References

\section{APPENDICES}

Appendix A HTI Document Control Checklist $\quad 15$

Appendix B Sample Project Records Index 16

Appendix C HTI Requirements Database Change Request Form 20

\section{FIGURES}

Figure I Desk Instruction Coverage of Configuration Management 1

Figure II Document \& Electronic File Control Flow 5

Figure III Roles \& Responsibilities Matrix 7

Figure IV Information \& Documentation Management Flow 10 


\section{HNF-SD-HTI-CMD-001, Rev. 0 \\ HTI Configuration Management Desk Instruction \\ 1.0 Desk Instruction Purpose}

As a project under the Tank Waste Remediation System (TWRS) program, HTI is subject to WHC-SD-WM-CM-013, the "TWRS Configuration Management Program Plan" (CMPP), which complies with DOE Standard DOE-STD-1073-93, "Guide to Operational Configuration Management." The CMPP integrates technical and administrative control to establish and maintain consistency among requirements, product configuration, and product information during all phases of the product's life cycle.

Configuration Management consists of five elements as described in Figure I below. Note that controlled copies of all referenced materials are retained in the HTI Working File (see Section 3.2).

\section{FIGURE I}

Desk Instruction Coverage of Configuration Management

\begin{tabular}{|c|c|c|c|}
\hline CM Element & Definition & DI Section & Other Sources \\
\hline Program Element & $\begin{array}{l}\text { Direct/monitor the development and } \\
\text { implementation of overall CM } \\
\text { program. Includes Program } \\
\text { Planning, Equipment Scope Criteria, } \\
\text { Concepts/Terminology, Interfaces, } \\
\text { Databases, and Procedures. }\end{array}$ & $2.0^{*}$ & $\begin{array}{l}\text { WHC-SD-WM-CM-013 } \\
\text { TWRS CM Program Plan } \\
\text { WHC-SD-WM-CM-014 } \\
\text { TWRS CM Program } \\
\text { Implementation Plan }\end{array}$ \\
\hline Design Requirements & $\begin{array}{l}\text { Establish/maintain the design } \\
\text { requirements and the associated } \\
\text { design basis. }\end{array}$ & $\begin{array}{l}3.0 \\
5.0 \\
6.0\end{array}$ & $\begin{array}{l}\text { WHC-SD-WM-CM-013 } \\
\text { TWRS CM Program Plan } \\
\text { WHC-CM-6-1 } \\
\text { Std. Eng. Practices }\end{array}$ \\
\hline Document Control & $\begin{array}{l}\text { Identify/maintain documents within } \\
\text { the } \mathrm{CM} \text { program, consistent with the } \\
\text { physical configuration and design } \\
\text { requirements. }\end{array}$ & $\begin{array}{l}3.0 \\
5.0 \\
6.0\end{array}$ & $\begin{array}{l}\text { WHC-SD-WM-MP-003 } \\
\text { HTI Information } \\
\text { Management Plan }\end{array}$ \\
\hline Change Control & $\begin{array}{l}\text { Maintain consistency among the } \\
\text { design requirements, physical } \\
\text { configuration, and the facility } \\
\text { documentation as changes are made. }\end{array}$ & $\begin{array}{l}3.0^{*} \\
2.3^{*}\end{array}$ & $\begin{array}{c}\text { HNF-CM-2-5 } \\
\text { Management Control System } \\
\text { HNF-CM-6-1 } \\
\text { Std. Eng. Practices }\end{array}$ \\
\hline
\end{tabular}


HNF-SD-HTI-CMD-001, Rev. 0

\begin{tabular}{|l|l|c|c|}
\hline Assessments & $\begin{array}{l}\text { Define facility configuration } \\
\text { management needs and measure how } \\
\text { effective CM program is in } \\
\text { establishing/maintaining the } \\
\text { program's basic relationships. }\end{array}$ & $\begin{array}{c}4.0^{*} \\
\text { WHC-SD-WM-CM-013 } \\
\text { TWRS CM Program Plan } \\
\text { WHC-SD-WM-CM-014 } \\
\text { TWRS CM Program } \\
\text { Implementation Plan }\end{array}$ \\
\hline
\end{tabular}

${ }^{*}$ By reference only.

This desk instruction provides references to project management level Program Management and Assessment CM activities, and provides working level directions for submitting requirements and project documentation related to the Hanford Tanks Initiative (HTI) project. This includes documents and information created by HTI, as well as non-HTI generated materials submitted to the project. It is intended to provide HTI team members with simple instructions for getting information into the appropriate approval, distribution and filing systems, and to be compliant with applicable configuration management and control requirements. The "HTI Document Control Checksheet" (Appendix A) should be used as a template for processing and tracking database changes and documents. The checksheet is offered as an optional aide, and is not to be retained in the permanent files.

The change and document control systems described here-in provide project management with visibility into, and control over changes which affect the project. These systems also provide centralized, shared access to accurate, consistent and timely information for all HTI participants. This access will facilitate the coordination of efforts for the efficient execution of the project mission. The systems also provide a change history and traceability to source documents and to decision making logic. The described processes meet all relevant configuration management, systems engineering and site document control and record keeping requirements.

\subsection{Program Management Element}

The Program Management element establishes oversight for configuration management, and provides for CM integration among participants to ensure the integrity and quality of the baseline, processes, and implementing procedures. It includes:

Program Planning

CM Training

Vendor and Contractor Control

Interfaces

Procedures 
HNF-SD-HTI-CMD-001, Rev. 0

See WHC-SD-WM-CM-013, "TWRS Configuration Management Program Plan" and WHC-SD-WM-CM-014, "TWRS Configuration Management Program Implementation Plan" for specific directions.

\subsection{HTI Requirements Database Change \& Document Control Systems Descriptions}

The requirements database change and document control functions are separate, but linked systems. The requirements database system manages HTI design requirements, using an automated database. The document control system manages all HTI generated and received records, documents and files, including those produced by the requirements database system, using existing Hanford site document control resources. This also includes both hard copy and electronic files generated internally and received from external sources, such as vendors. Vendor files include a wide variety of media, such as zip drives, photo CD-ROMs, etc.

For changes to the technical scope of work, cost and schedule baselines, related to the Change Control Process, see Hanford site standard HNF-CM-2-5, "Management Control System". This control manual provides a step-by-step- instruction for formal change control.

\subsection{Requirements Datahase System}

The Requirements Driven Design-100 (RDD-100) database is the computer software system used for controlling requirements and related data changes. The database controls design information, including requirements, specifications, issues, functions, architectures, flows, etc. It also produces requirements related documents including:

Specifications

Functions \& Requirements (F\&R) Documents:

F\&R Allocation Sheets

Design Constraint Forms

Interface Control Descriptions

Issues Lists

Other Custom Reports \& Documents

HTI technical leads and subject matter experts serve as Gatekeepers for submitting data into the HTI Requirements Database, for their respective areas of responsibility. (See Figure III for a list of Gatekeepers). The Gatekeepers review, revise and/or approve all changes to the database, and submit them to the database administrator for entry. Once entered into the database, the requirements system processes, stores and formats changes for incorporation into printed documents and/or for viewing using the RDD-100 Browser.

Note that not all changes require the generation and/or distribution of revised requirements documents. The administrator of the requirements database normally compiles 
HNF-SD-HTI-CMD-001, Rev. 0

minor changes until the document owner and/or Gatekeeper decides to issue a revised document. To revise documents, the database system incorporates accumulated changes and produces a document for delivery to the document owner or Gatekeeper. Document Owners/Gatekeepers are then responsible for entering the document into the HTI Document Control System.

\subsection{Document Control System (DCS)}

The document control system is intended to collect, distribute, store, and control all documents and communications generated and/or received in support of the HTI project, as shown in Figure II. This includes all letters, study reports, action item lists, authorizations, telephone communication notes, etc. It also includes documentation produced within the project, as well as materials submitted to the project from outside sources. Appendix B provides a standardized index used by DCS for organizing project files. It is included as a reference as to the types of information subject to the document control system.

HTI electronic files will have a parallel structure to the DCSC hard file list in Appendix $\mathrm{B}$, and will be stored at three levels, including RMIS, project and individual working files. Electronic files will be stored on a shared drive designated for the HTI project. Higher level files will be password protected, and available to HTI participants as read only. File custodians, as described in Section 5 will have a read-write capability on these directories. Electronic media to be stored and controlled include photo-CDs, zip drives, videos, as well as more conventional shared drive access to document files.

The HTI project uses existing Hanford documentation and records management resources for document control. The Lockheed Martin Services Inc., Documentation and Records Management group provides site-wide information management and document control services. These services include the operation of localized Document Control Service Centers (DCSC) which process incoming documents and maintain HTI project files. The services provided by the centers include document scanning, indexing, document release, document clearance, distribution, and storage, as required. The DCSC located in 2440 Stevens, room 1512, houses the HTI Project File, supported by an assigned HTI Project File Custodian located in room 1310. A listing of other DCSC locations is available on the HLAN (Hanford Information), under "Document Service Centers."

In addition to the project files maintained by Documentation and Records Management, a duplicate set of files will be maintained and controlled as working files in the Project Office, for use by HTI personnel. The Working File Custodian function is also being performed by the DCSC Project File Custodian at this time.

In addition to the HTI files described, controlled copies of all documents referenced in this desk instruction will be maintained in the HTI working file. 
HNF-SD-HTI-CMD-001, Rev. 0

\section{FigureII}

Document \& Electronic File Control Flow 
HNF-SD-HTI-CMD-001, Rev. 0

\section{Originators' Documents \& Electronic Files}

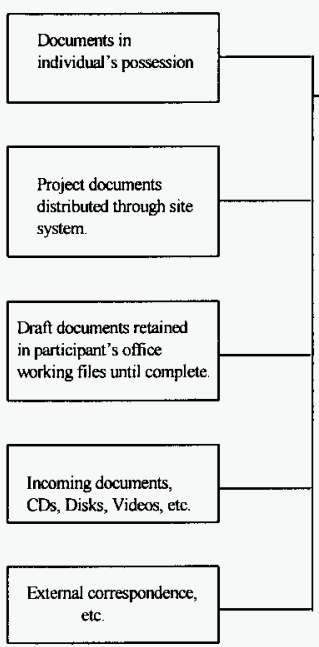

- With Gatekeeper Concurrence

\author{
Working File \\ Custodian **
}

Place in "HTI Filing" Basket

using flags to identify:

Copy-send to requestor, plus

Project \& Working files. File-

Project \& Working files.

FYl-Reference copy to

Working file only.

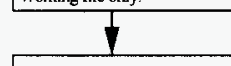

Electronic Data

Mgmt Processing

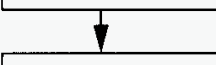

Duplicate documents as needed. Send to project file, then "hold" documents until RMIS indexing info. provided by PFC.

Apply file codes provided by PFC to working file copy \& engineer's copy, file in

appropriate working file (i.e., overall $\mathrm{HTI}$, characterization, closure, or retrieval) \& return originator's copy
Project File

Custodian **

Apply file code

ID project (ie., overall

HTI, Closure,

Characterization, or

Retrieval)

ID file code

Index documents into

RMIS

File documents

accordingly

Provide RMIS indexing as

new/updated documents

are received

Provide RMIS report

\subsection{Review \& Sign-off Authority (R/SA)}

** WFC and PFC services are currently being provided by the PFC 
HNF-SD-HTI-CMD-001, Rev. 0

Changes that affect the technical or performance baseline (Class I Changes), require dispositioning by the PHMC Change Board and the RL TWRS Director. Changes that affect the scope, schedule and/or budget at the cost account level of the project (Class II Changes) require PHMC Change Control Board approval. For such changes, see HNF-CM-2-5 for instructions.

Other changes that do not affect baseline cost, scope or schedule (Class III Changes) require dispositioning by the HTI Project Manager for verification of implementation. The HTI Project Office is responsible for configuration management of the project's baseline documents. All changes must be approved by the HTI Project Manager and the technical leads for the Demonstrate Retrieval Technologies In-Tank, Establish Closure Basis and Implement Closure subprojects.

Changes are submitted to the cognizant technical lead for initial review and approval. They are then either implemented or submitted directly to the Project Manager, as determined by the technical lead.

\subsection{Assessments}

The Assessment element of $\mathrm{CM}$ defines facility configuration management needs and measures the effectiveness of the CM program in establishing and maintaining the program's basic relationships, throughout the life of the facility. As described in DOE-STD-1073-93, "Guide to Operational Configuration Management" assessments includes:

Programmatic Assessments:

Initial Assessments

Post-implementation Assessments

Periodic Effectiveness Assessments

Vendor and Contractor Assessments

Technical Reviews, Audits and Assessments

Physical Configuration Assessments

Periodic Equipment Performance Monitoring

Post-Modification Testing

See WHC-SD-WM-CM-013, "TWRS Configuration Management Program Plan" and WHC-SD-WM-CM-014, "TWRS Configuration Management Program Implementation Plan" for specific directions.

\subsection{Roles \& Responsibilities}


HNF-SD-HTI-CMD-001, Rev. 0

The following sections (5.1-5.6) provide a top level description of the information and documentation control roles of each participant. See Section 6.0 for detailed instructions and examples. The following matrix is a directory of HTI performers, provided to facilitate processing.

FIGURE III

ROLES \& RESPONSIBLITIES MATRIX

\begin{tabular}{|l|l|l|l|}
\hline \multicolumn{1}{|c|}{ Role } & \multicolumn{1}{c|}{ Name } & \multicolumn{1}{c|}{ Title } & \multicolumn{1}{c|}{ Area of Concern } \\
\hline Gatekeepers: & Bill Root & Project Manager & HTI Project Management \\
\hline & Al Noonan & Subject Matter Expert & Characterization \\
\hline & Larry McDaniel & Technical Lead & $\begin{array}{l}\text { Dem. Retrieval Tech. In-Tank } \\
\text { Subproject }\end{array}$ \\
\hline & Ed Fredenburg & Technical Lead & Establish Closure Basis Subproject \\
\hline & John Bloom & Subject Matter Expert & Environmental Safety \& Health \\
\hline & Jeff Huston & Subject Matter Expert & Quality Assurance \\
\hline & Steve Schaus & Subject Matter Expert & Systems Engineering \\
\hline $\begin{array}{l}\text { HTI Project Files } \\
\text { Custodian }\end{array}$ & Finette Wickstrand & Records Specialist & Technology Alternatives Subproject \\
\hline $\begin{array}{l}\text { HTI Work } \\
\text { Files Custodian }\end{array}$ & Finette Wickstrand & Records Specialist & Document Control Service Center \\
\hline $\begin{array}{l}\text { Requirements } \\
\text { Database } \\
\text { Administrator }\end{array}$ & Ron Barden/TRW & Project Engineer & Requirements Database \\
\hline
\end{tabular}

\subsection{Document \& Change Originators}

Develop changes, original documents, drawings, records, electronic files etc., or receive documents, CDs, videos, disks, etc., from outside HTI.

Prepare justification notices and explanations as required.

Prepare necessary cover pages and forms.

Prepare distribution lists, to include HTI Project File and Working File Custodians.

Obtain required signatures and authorizations, through cognizant Gatekeeper(s). 
HNF-SD-HTI-CMD-001, Rev. 0

Submit approved package into appropriate system:

Requirements Database, through Gatekeepers, for requirements and specification changes, or

DCS for new changed or received documents and records, with gatekeeper approval.

\subsection{Gatekeepers (GK)}

Review changes, original documents, etc. for correctness, concurrence and approval for entry into the system, etc.

Comment on, or correct submittals, as necessary.

Provide change authorization by signature, or through HTI Project Manager, etc.

Submit the database change packages to the Requirements Database Administrator.

Return completed/approved documents to originator for processing through DCSC, or submit documents prepared by the Requirements database administrator to DCSC directly.

Review documents for impact on the requirements database, and channel information into database as necessary.

\subsection{Requirements Database Administrator (RDA)}

Review changes for adherence to data structure rules.

Sign-off on Database Change Request, prior to data entry.

Input authorized changes into the RDD-100 database.

Maintain Browser and Control Files.

Prepare necessary or requested documents for signature and distribution.

Return completed documents Gatekeeper for processing by DCS.

\subsection{DCS Service Centers (DCSC)}

Process packages as necessary, according to the "Document Control \& Records Management Manual"' (HNF-CM-3-5).

Distribute released documents per the distribution list provided (to include HTI Project File and Working File Custodians).

\subsection{HTI Project File Custodian (PFC)}

Sort and file by subproject.

Maintain files.

Control access to files.

Index files.
Process Electronic Files.

Set file name and location.

Ensure password protection.

Enter electronic file to shared drive. 
HNF-SD-HTI-CMD-001, Rev. 0

Provide copies as requested. Maintain/update designated files on HTI shared drive.

\subsection{HTI Working File Custodian (WFC)}

Receive documents, etc. from originators, sort and process by subproject.

Submit documents, etc. to Project File Custodian for processing.

Maintain updated working files in HTI Project office.

Control access to working files.

Verify electronic documents match hard copy of documents.

Provide copies as requested.

Maintain controlled copies of all documents referenced in the desk instruction. 


\subsection{Processes}

The following processes are designed to facilitate the flow of documents and records from their originators, through appropriate approval cycles, and into working and project files. Figure IV provides an overview of the processes to guide users to the appropriate process to meet their needs.

FIGURE IV

\section{Information \& Documentation Management Flow}

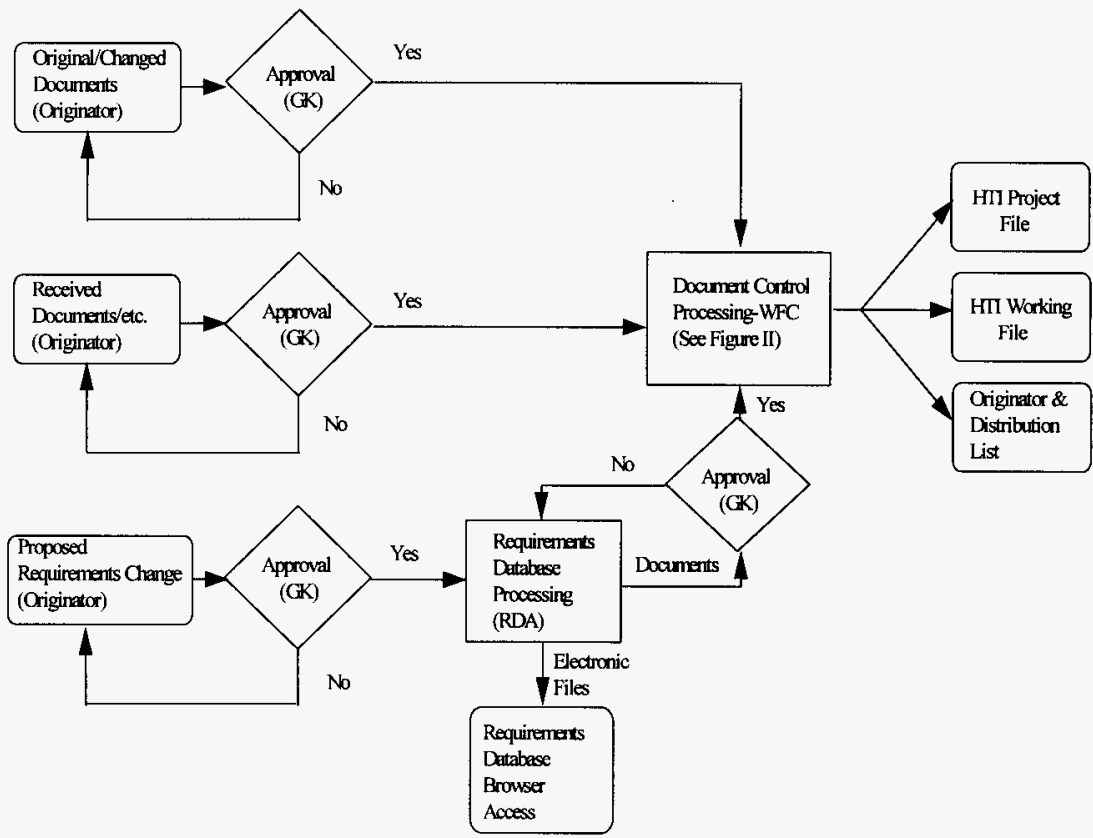

Note that all documents, data, and information relevant to the HTI project should eventually end 
HNF-SD-HTI-CMD-001, Rev. 0

up in the permanent project file and the HTI working file. They are processed through the gatekeepers for review and approval, and then to WFC for entry into the DCS.

\subsection{Submitting Documents Received From Outside HTI}

\begin{tabular}{|c|c|c|}
\hline STEP & BY & PROCESS \\
\hline A & Originator & $\begin{array}{l}\text { Prepare brief informal cover memo of } \\
\text { explanation. }\end{array}$ \\
\hline B & Originator & Submit to cognizant GK. \\
\hline $\mathrm{C}$ & GK & $\begin{array}{l}\text { Review and approve for permanent filing in } \\
\text { the DCS. }\end{array}$ \\
\hline $\mathrm{D}$ & GK & Review for impact on requirements database \\
\hline $\mathrm{E}$ & GK & Return to originator. \\
\hline $\mathrm{F}$ & Originator & $\begin{array}{l}\text { Submit to WFC, with flags identifying } \\
\text { distribution. }\end{array}$ \\
\hline G & WFC & $\begin{array}{l}\text { Process (See Figure II, Document Control } \\
\text { Flow) }\end{array}$ \\
\hline
\end{tabular}

\subsection{Submitting Requirements Changes}

\begin{tabular}{|c|c|c|}
\hline$\underline{\text { STEP }}$ & $\underline{\mathrm{BY}}$ & PROCESS \\
\hline A & Originator & $\begin{array}{l}\text { Prepare necessary HTI Requirements } \\
\text { Database Change Request (See Appendix C) }\end{array}$ \\
\hline B & Originator & Submit requirements change package to GK \\
\hline $\mathrm{C}$ & GK & $\begin{array}{l}\text { Review/revise, approve/sign-off or consult } \\
\text { with other GKs and/or Project Manager for } \\
\text { approval/sign-off. }\end{array}$ \\
\hline D & GK & Submit to RDA \\
\hline E & RDA & $\begin{array}{l}\text { Review for proper database structure, } \\
\text { revise/consult with originator and approve } \\
\text { for data entry }\end{array}$ \\
\hline
\end{tabular}


HNF-SD-HTI-CMD-001, Rev. 0

$\begin{array}{ccl}\frac{\text { STEP }}{\mathrm{F}} & \underline{\mathrm{BY}} & \begin{array}{l}\text { PROCESS } \\ \text { PDA } \\ \text { geness changes/prepare RDD-100 documents if requested. }\end{array} \\ \mathrm{G} & \mathrm{RDA} & \begin{array}{l}\text { Return RDD-100 documents to GK, } \\ \text { if generated. }\end{array} \\ \mathrm{H} & \mathrm{GK} & \begin{array}{l}\text { Return RDD-100 document with authorizing } \\ \text { signature(s) to originator or owner. }\end{array} \\ \mathrm{I} & \text { Originator } & \text { Obtain other approval signatures, if required } \\ \mathrm{J} & \text { Originator } & \text { Deliver to WFC for processing } \\ \mathrm{K} & \text { WFC } & \begin{array}{l}\text { Begin DCS Processing (See Figure II, } \\ \text { Document Control Flow). }\end{array}\end{array}$

\subsection{Changing or Submitting Documents Generated by HTI}

$\begin{array}{cc}\text { STEP } & \text { BY } \\ \text { A Originator } & \begin{array}{l}\text { PROCESS } \\ \text { Request Document Identification Number } \\ \text { for Rev. 0 documents from the DCSC. }\end{array} \\ \text { B Originator } & \begin{array}{l}\text { Prepare necessary cover sheets \& form: } \\ \text { (See HNF-CM-6-1, on the HLAN (Hanford } \\ \text { Info) under "Company Wide Control } \\ \text { Manuals" for forms and instructions): }\end{array} \\ & \text { - Engineering Change Notice for Rev. } 1 \\ \text { and higher revisions (GEF 094, GEF 095 } \\ \text { and GEF 096) } \\ \text { - Record of Revision (ROR) explaining } \\ \text { why the change was made. (WEF 168) } \\ \text { - Form BD-7400-172-2 (GEF 097) }\end{array}$


HNF-SD-HTI-CMD-001, Rev. 0

"Engineering Data Transmittal" for all Rev. 0 documents and drawings

\begin{tabular}{|c|c|c|}
\hline STEP & $\underline{B Y}$ & $\begin{array}{l}\text { PROCESS } \\
\text { - Distribution list, to include the HTI } \\
\text { Working File \& Project File Custodians } \\
\text { (WEF 067) } \\
\text { - Information Release Request Form } \\
\text { (A-6000-401 or A-6001-401.1) }\end{array}$ \\
\hline $\mathrm{C}$ & Originator & Submit to GK for review/comment/approval \\
\hline $\mathrm{D}$ & GK & $\begin{array}{l}\text { Review/revise, approve/sign-off or submit to } \\
\text { HTI Program Manager for approval/sign-off, } \\
\text { or for upper level review and approval, if } \\
\text { necessary. }\end{array}$ \\
\hline $\mathrm{E}$ & GK & Review for impact on requirements database \\
\hline $\mathrm{F}$ & GK & $\begin{array}{l}\text { Return document with authorizing } \\
\text { signature(s) to originator }\end{array}$ \\
\hline $\mathrm{G}$ & Originator & Deliver to WFC for processing \\
\hline $\mathrm{H}$ & WFC & $\begin{array}{l}\text { Begin DCS Processing (See Figure II, } \\
\text { Document Control Flow) }\end{array}$ \\
\hline I & WFC & $\begin{array}{l}\text { Compare electronic copies against hard copy } \\
\text { original for accuracy, after distribution, etc. } \\
\text { and file. }\end{array}$ \\
\hline
\end{tabular}

\subsection{Retrieval of Documents \& Review of Unpublished Changes}

Contact the HTI Project or Working File Custodians to obtain or view released documents, etc. Contact the Requirements Database Administrator for access to the database browser to review all unpublished changes to the requirements database. 
HNF-SD-HTI-CMD-001, Rev. 0

\subsection{References}

- DOE-STD-1073-93, Guide to Operational Configuration Management

- DOE/RL-93-0106, Tank Waste Remediation System Program Management System Description

- HNF-CM-2-5, Management Control System

- HNF-CM-3-5, Mnagement Manual Document Control \& Records

- HNF-CM-6-1, Standard Engineering Practices Control Manual

- WHC-SD-WM-CM-013, Tank Waste Remediation System Configuration Management Program Plan

- WHC-SD-WM-CM-014, TWRS CM Program Implementation Plan

- WHC-SD-WM-MP-003, Draft Hanford Tanks Initiative Information Management Plan

- WHC-SD-WM-PMP-022, Rev. 0, Draft Hanford Tanks Initiative Plan. 
HNF-SD-HTI-CMD-001, Rev. 0

Appendix A.

HTI Document Control Checksheet

Subproject:

Subproject Engineer/Gatekeeper:

Summary of Required Change:

A. Requirements Changes:

By Date

1. Forms completed:

- Requirements Database Change Request

- Engineering Change Notice (for DCS docs only)

- Record of Revision (for DCS docs only)

- SD Coversheet or IRR Form (for DCS docs only)

2. Submitted for approval to:

3. Approved by:

- Gatekeeper

- Change Control Board (By Gatekeeper)

- HTI Project Manager (By Gatekeeper)

4. Submitted to RDD-100 Administrator by Gatekeeper

5. Changes Incorporated Into RDD-100 By Administrator

6. RDD-100 Documents Returned by Gatekeeper

7. Documents Submitted to Working File Administrator

B. Document Changes or Submittals:

By Date

1. Document Identification Number from DCSC

2. Forms:

- Engineering Change Notice

- Record of Revision

- Engineering Data Transmittal

- Distribution List

- Release Authorization Form

3. Submitted for approval to:

4. Approved by: - Gatekeeper

- HTI Project Manager

- Change Control Board (By Gatekeeper)

5. Documents Submitted to Working File Administrator 
HNF-SD-HTI-CMD-001, Rev. 0

\section{Appendix B}

Sample Project Records Index

(3 pages to follow) 
HNF-SD-HTI-CMD-001, Rev. 0

PROJECT RECORDS INDEX

0.0 PROJECT RECORDS INDEX/PACKAGE ACCEPTANCE RECORD

1.0 ADMINISTRATIVE

1.1 CORRESPONDENCE

1.1.1 A/E CORRESPONDENCE

LETTER OF INSTRUCTION

LETTERS/MEMOS

DSIs/CC:MAIL

1.1.2 CC CORRESPONDENCE

LETTER OF INSTRUCTION

LETTERS/MEMOS

DSIs/CC:MAIL

1.1.3 OC CORRESPONDENCE

LETTER OF INSTRUCTION

LETTERS/MEMOS

DSIs/CC:MAIL

1.1.4 RL CORRESPONDENCE

LETTER OF INSTRUCTION

LETTERS/MEMOS

DSIS/CC:MAIL

1.1.5 OTHER CORRESPONDENCE

1.2 TRANSMITTALS

1.3 TELEPHONE RECORDS

1.4 MEETING MINUTES

1.5 TRIP/CONFERENCE REPORTS

1.6 PROGRESS REPORTS/STATUS REPORTS

QUARTERLY

MONTHLY

WEEKLY

FIELD CONTRACT ENGINEER DAILY FIELD REPORTS

1.7 REVIEW COMMENTS/DATA

1.8 PHOTOGRAPHS

1.9 KEY DECISIONS/MILESTONES

1.10 OTHER ADMINISTRATIVE DOCUMENTS

2.0 PLANNING (INPUTS)

2.1 ENGINEERING STUDY/LETTER REPORTS

2.2 SUPPLEMENTAL DESIGN REQUIREMENTS DOCUMENT

2.3 CONCEPTUAL DESIGN REPORTS

2.4 FUNCTIONAL DESIGN CRITERIA 
HNF-SD-HTI-CMD-001, Rev. 0

PROJECT RECORDS INDEX

2.5 SITE EVALUATION

2.6 MANAGEMENT PLANS

2.7 PROJECT PLAN

2.8 WORK PLANS

2.9 SCHEDULES

2.10 STATEMENT OF WORK

2.11 PROJECT START-UP CHECKLIST

2.12 VALUE ENGINEERING

2.13 TECHNICAL DATA CHECKLIST

2.14 PLANT FORCES WORK REVIEW

2.15 OTHER PLANNING DOCUMENTS

3.0 DESIGN (OUTPUTS)

3.1 DRAWINGS

3.2 CALCULATIONS

3.3 SPECIFICATIONS CONSTRUCTION

PROCUREMENT

GENERAL

3.4 DESIGN VERIFICATION

3.5 OTHER DESIGN DOCUMENTS

4.0 FINANCIAL

4.1 PROJECT AUTHORIZATION/MODIFICATION

4.2 WORK ORDERS

4.3 CHANGE REQUESTS

4.4 ENGINEERING CONSTRUCTION CHANGE

4.5 ESTIMATES

4.6 JUSTIFICATION FOR NEW START/MISSION NEED

4.7 PURCHASE ORDERS

4.8 OTHER FINANCIAL DOCUMENTS

5.0 SAFETY

5.1 PRELIMINARY SAFETY EVALUATION

5.2 FIRE HAZARDS/PROTECTION/SAFETY CLASSIFICATION

5.3 PRELIMINARY/FINAL SAFETY ANALYSIS REPORT

5.4 PRE-JOB SAFETY PLANNING/JOB SAFETY ANALYSIS

5.5 OTHER SAFETY DOCUMENTS

6.0 ENVIRONMENTAL

6.1 ASSESSMENTS/EVALUATIONS

6.2 IMPACT STATEMENT 
HNF-SD-HTI-CMD-001, Rev. 0

6.3 RESOURCES REVIEWS

PROJECT RECORDS INDEX

6.4 HEHF REPORTS

6.5 OTHER DOCUMENTATION (NEPA)

7.0 QUALITY ASSURANCE

7.1 QUALITY ASSURANCE PLANS

7.2 ASSESSMENTS

7.3 OTHER QUALITY ASSURANCE DOCUMENTS

8.0 CONSTRUCTION (OUTPUTS)

8.1 PERMITS

8.2 SURVEY DATA

8.3 A/E ENGINEERING CHANGE NOTICES

8.4 OC ENGINEERING CHANGE NOTICES

8.5 PROCESS CONTROL PACKAGES

8.6 SUBMITTALS

8.7 RECORD OF FIELD WALKDOWNS

8.8 CONTRACT DOCUMENTS

8.9 OTHER CONSTRUCTION DOCUMENTS

9.0 QUALITY CONTROL

9.1 ACCEPTANCE TEST PROCEDURES/ REPORTS

9.2 INSPECTION PLANS

9.3 SITEWORK RECORDS

9.3.1 CONCRETE RECORDS

9.3.2 MECHANICAL RECORDS

9.3.3 ELECTRICAL RECORDS

9.4 PRESSURE TEST CERTIFICATIONS

9.5 INSPECTION REPORTS

9.6 NONCONFORMANCE REPORTS

9.7 WELD RECORDS/WELD MAPS

9.8 PUNCHLISTS/DEFICIENCY REPORTS

9.9 MEASURING AND TEST EQUIPMENT USE RECORD

9.10 CRITICAL LIFT PROCEDURES

9.11 DRILL LOGS

9.12 GENERAL INSPECTION LIST/SURVEILLANCE REPORTS

9.13 OTHER QUALITY CONTROL RECORDS

10.0 CLOSEOUT

10.1 ENGINEERING FINAL DESIGN CHECKLIST 
HNF-SD-HTI-CMD-001, Rev. 0

10.2 WORK ACCEPTANCE

10.3 OFFICIAL ACCEPTANCE OF CONSTRUCTION

10.4 LESSONS LEARNED

10.5 CONSTRUCTION COMPLETION AND COST CLOSING STATEMENT (4Cs)

Appendix C

HTI Requirements Database Change Request Form

HTI Requirements Database Change Request (DCR Form)

Samples of Backup Materials 
HNF-SD-HTI-CMD-001, Rev. 0

\section{HTI REQUIREMENTS DATABASE CHANGE REQUEST (DCR)}

\section{APPENDIX C}

DCR number: 000

EFFECTED DOCUMENT (FRD, PDC, WRS Spec, etc):

DATE of .mdb/.im file:

TODAY'S DATE:_12/17/96 CHANGE PROPOSED BY (your name): M. Leonard

ORGANIZATIONS AFFECTED (who you think will be affected by change):

ACTR

Project Lead

HSTB / TWRS-SE
C-106 Retrieval OTHER(specify) (Date of affected version)

\section{SUMMARY OF PROPOSED CHANGE:}

Example data input format for SystemRequirements. Also gives examples on how to change data already in database (C-106 Retrieval Demonstration System Component)

WHY IS THE CHANGE NEEDED (benefit of change):

Communicate to HTI Leads and Team members how to change to the database.

SPECIFIC CHANGES TO DOCUMENT (as needed, provide attachment of affected pages with pen \& ink or similar markups clearly showing proposed changes):

See Attached

TEAM LEAD REVIEW (others as needed):

\begin{tabular}{||l|l|l|l||}
\hline & & & \\
\hline J.A. Yount, ACTR & Date & L.B. McDaniel, C-106 Ret. & Date \\
\hline \hline & & & \\
\hline E.A. Fredenburg, Closure & Date & P.S. Schaus, SE Lead & Date \\
\hline \hline & & & \\
\hline & Date & F\&R database & Date \\
\hline
\end{tabular}

ADMINISTRATIVE

\begin{tabular}{|l|l|l|l|}
\hline & & & \\
\hline & Date & Database Admin. & Date \\
\hline & & & \\
\hline Incorporated by: & Date & & Date \\
\hline
\end{tabular}


HNF-SD-HTI-CMD-001, Rev. 0

APPENDIX C

CHANGE IMPLEMENTED: (Requestor)

\section{Example SystemRequirement Data Input Form \\ Attributes and Relationships}

Element Type: SystemRequirement

Element Name: Enter Name of SR IAW TWRS RDD-100 Users's Guide (Section 3.2)

Element Number:

\section{ATTRIBUTES}

creator: RDD Auto entry

creationDate: RDD Auto entry

modificationDate: RDD Auto entry

modificationTime: RDD Auto entry

description: Enter Requirement text

requirementType: null (if Constraint), Performance, Functional, Design Constraint

title: Give Requirement Title. For Derived requirements this is the string that prints as the Spec. Section title

projectUniquelD: For Constraints, TWRS; For Derived Requirements, HTI or null

\section{RELATIONS}

Relation: categorized_by

Related Type: Category

Related Number:

Related Name: Constraint or Derived

Relation: documented_by or incorporated_by

Related Type: Source or SystemRequirement

Related Number:

Related Name: 
HNF-SD-HTI-CMD-001, Rev. 0

APPENDIX C

\section{Conditional Relationships}

Relation: raises

Related Type: Criticallssue

Related Number:

Related Name:

Relation: resulted_from

Related Type: Decision

Related Number:

Related Name:

If Category = Derived", then:

Relation: traces_to

Related Type: Component or TimeFunction

Related Number:

Related Name:

Relation: verified_by

Related Type: VerificationRequirement

Related Number:

Related Name: 
HNF-SD-HTI-CMD-001, Rev. 0

\section{Example Component Change}

Element Type: Component

Element Name: RetrievalDemenstration Suppert Persennel Waste Removal System Element Number: 2.1

\section{ATTRIBUTES}

creator: Hanford Tanks Initiative

creationDate: $08 / 29 / 96$

modificationDate: $09 / 26 / 96$

modificationTime: $14: 44: 17$

description: Retrievalopentions operate, disasemble and maintain the waste retrieval gystem being tested. This also ineludes any-supplies (spares) and tool kits (wrenehes,

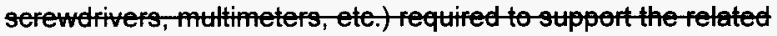

aetivities.

Off-site vendor supplied Waste Removal System (WRS) that consists of equipment required to: (a) deploy the waste removal tool to the 241 C-106 tank Waste surface and back out of the tank. (b) remove the waste from 241:C106) (c) provide the motive force for transferring waste to DST storage: and (d) control and monitor the WRS during operation.

componentType: System Segment

status: Pending

approvedBy:

RELATIONS

Relation: traced_from

Related Type: SystemRequirement

Related Number:

Related Name: DOE 5480.11A, 5480.10 ; WHC-CM-4-11, Appendix 7-B 


$$
\text { HNF-SD-HTI-CMD-001, Rev. } 0
$$

Relation: traced_from

Related Type: SystemRequirement

Related Number:

Related Name: DOE Order 5480.11 9.j(1)(d); WHC-CM-4-9, 4-11;

ORNL/TM-10864

Relation: traced_from

Related Type: SystemRequirement

Related Number:

Related Name: DOE Order 5480.11, W-340-0 C1, F\&A ISU1

Relation: traced_from

Related Type: SystemRequirement

Related Number:

Related Name: OSD-T-151-00013.3

Relation: traced_from

Related Type: SystemRequirement

Related Number:

Related Name: W-340-0 C1, ISU1, WHC-EP-0352

Relation: resulted_from

Related Type: Decision

Related Number:

Related Name: HTI Tank Farm Retrieval Architecture Enabling Assumption

Relation: owned_by

Related Type: Engineer

Related Number: (ghost)

Related Name: Hanford Tanks Initiative

Relation: built in

Related Type: Component

Related Number: 2.0

Related Name: Tank Farm Retrieval Demonstration System

Relation: performs

Related Type: TimeFunction

Related Number: 1.2.3.84

Related Name: Deaetivate Tank Deploy Waste Removal System 
HNF-SD-HTI-CMD-001, Rev. 0

Relation: performs

Related Type: TimeFunction

Related Number: 1.2.3.36

Related Name: Remove Waste from 241-C-106

Relation: performs

Related Type: TimeFunction

Related Number: 1.2.3.40 7

Related Name: Maintain Retriensfer Waste to DST Storage

Relation: performs

Related Type: TimeFunction

Related Number: 1.2.3.59

Related Name: Opentrol and Monitor the WRS 


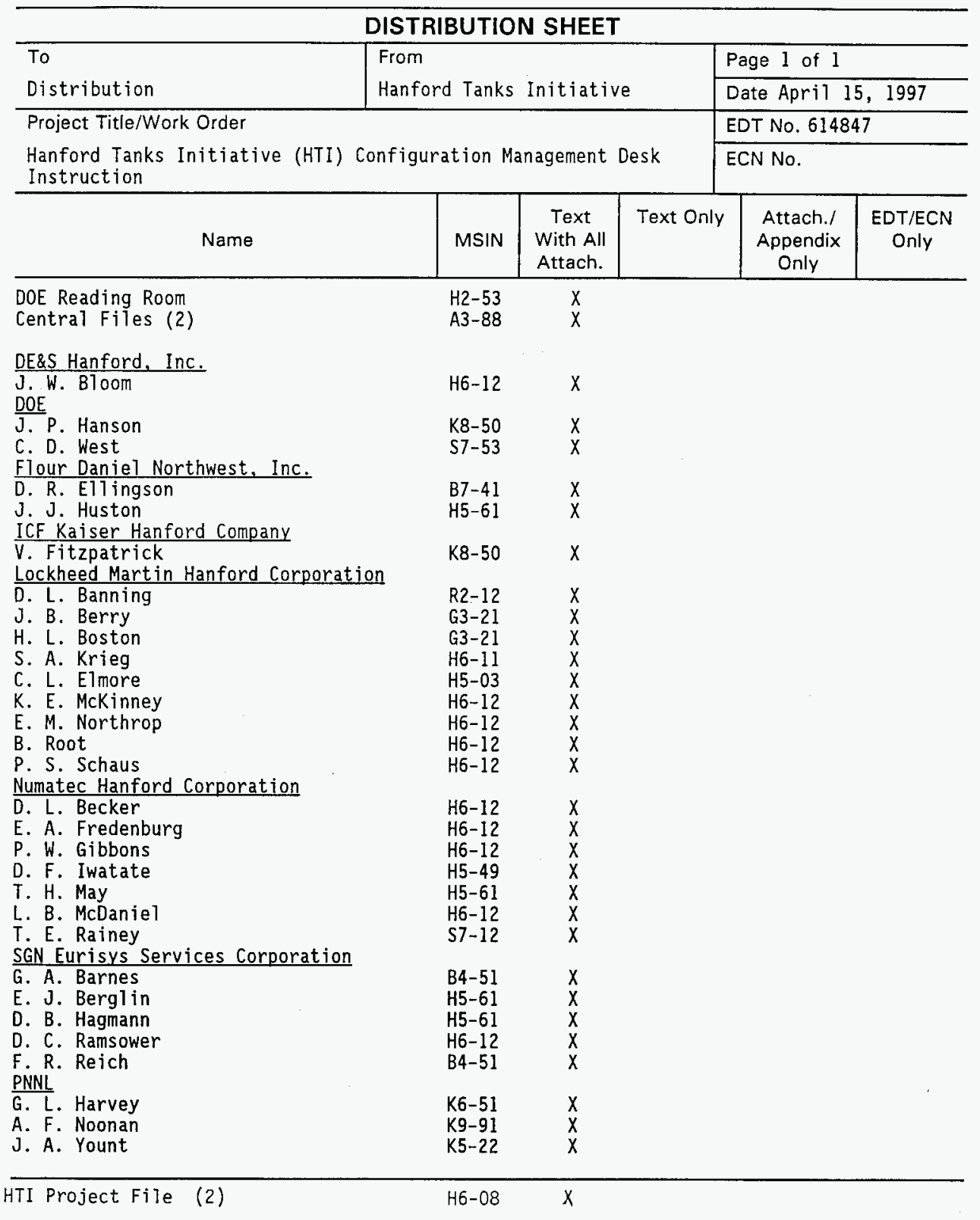

